Vol. 8, Issue 12, December 2021

DOI: 10.17148/IARJSET.2021.81205

\title{
ON SOME FRESHWATER ALGAE FROM KURNOOL DISTRICT, ANDHRA PRADESH, INDIA.
}

\author{
B.Shobha Rani ${ }^{1}$, Prof. P.Sujathamma ${ }^{2}$ \\ ${ }^{1,2}$ Department of Biosciences and Sericulture, Sri Padmavathi Mahila Vishwa vidyalayam, \\ Tirupati, Chittoor (Dt), Andhra Pradesh.
}

\begin{abstract}
Freshwater algae were collected in post rainy season from Kurnool district in the year 2019 and analyzed for taxonomic diversity. The collections yielded 40 species. Some algae were identified to species level, some to Genera level and some yet to be identified. Eleven Genera and Twenty one species were presented in this article. Scenedesmus represented 6 species, followed by Coelastrum with 3 species and Pseudopediastrum represented two species and a variety. Represented taxa are the new distributional records to Kurnool district.
\end{abstract}

Key words: Freshwater, diversity, Scenedesmus, Coelastrum, Pseudopediastrum.

\section{INTRODUCTION}

Alage are the main producers in all aquatic ecosystems. They range from microscopic unicellular, colonial, filamentous to macroscopic in their habit. Documentation of the diversity is essential to assess the distribution, conservation and sustainable utilization. Algae have been used as food, fodder, experimental tools in cytology, Physiology and genetics. Moreover, they are used in Industry and Pharmacy. It is evident from literature that the survey and documentation of diversity of freshwater Algae in India, especially in Andhra Pradesh is insufficient.

Kurnool district has several reservoirs and canals apart from Srisailam water reservoir which is the major source of water bodies in the district. Nallamalai forests and Yerramala forests have temporary water bodies which have not been explored for the diversity of freshwater algae. Hence this study gains importance.

\section{LITERATURE REVIEW}

It is evident from the website of Botanical Survey of India and the works of Gupta.R.K.(2012) that, 7411 species belong to 735 genera of Algae were recorded and described from India so far. Turner(1892) contributed to desmid flora of East India. Indian Council of Agriculture and Research published a series of Monographs on fresh water Algae authored by Desikachary TV (1959), Randhawa MS (1959), Philipose MT (1967), Iyengar and Desikachary 1981. Further Prasad BN and Mishra PK (1992) brought out the flora of Andaman and Nicobar.

Contributions to fresh water algal flora in Andhra Pradesh were made by Kaparapu and Geddada( 2013) Jyotsna et al., (2015), Kaparapu and Geddada( 2015), Rao and Pragada( 2010), Madhavarao and Rao( 2016), Rekha et al., (2016), Rekha and Sujathamma( 2017, 2018) Naidu et al., (2018) Nandigam et al., (2016).

\section{MATERIALS AND METHODS}

A total of 32 samples of Fresh water algae was collected from two localities of Velugodu Dam, Nandyal tank and a tank near Kurnool. Collections were initially packed in zipped covers. Microalgae were collected with the help of plankton net. Benthic algae were collected by suction. All samples were labeled with date of collection, collection number, place of collection and altitudes and latitudes were noted with the help of GPRS. Algal samples were preserved in 4\% Formalin and studied in the Department of Biosciences \& Sericulture Sri Padmavathi Mahila Vishwavidyalayam, Tirupathi.

Temporary and permanent slides were prepared by using the stains, Lugol's solution and Anilin blue. They were observed under already calibrated Olympus binocular bright field Hi 20 microscope. Microphotographs were taken with the help of Sony camera. Measurements were taken with the help of ocular micrometer. Characters were noted down for identification. 
The organisms were identified with the help of monographs, G.S.West (1905), Desikachary (1959), Randhava(1959), Philipose(1967), and other publications, Prescot(1961), Prasad and Misra (1992), Kanth and Guptha(1998) etc.,

\section{RESULTS}

\section{SYSTEMATIC ENUMERATION}

1. Coelastrum cambricum Archer, W. 1868.

Colonies spherical, 8 to 32 -celled around $70 \mu$ in diameter, Cells spherical and thickened at the poles, connected to each other by 4-6 short, truncate projections. Spaces between cells circular to triangular, $6-12 \mu$ in diameter.

Place of collection: Nandyal tank, Date of collection:12.11.2019 Collection number: 21

\section{Coelastrum microporum Nag. 1855.}

Colonies spherical, 8 to 16 celled, $32 \mathrm{um}$ broad; cells spherical, interconnected by gelatinous processes, intercellular spaces small, 7 um broad.

Place of collection: Kurnool tank , Date of collection:11.11.19,Collection number:02

3. Coelastrum proboscideum Bohlin,. 1877.

Colonies spherical, 8 to 16 celled, 30 um broad; cells truncately conical, thickened at poles, 10um wide.

Place of collection: Kurnool tank, Date of collection: 11.11.19, Collection number: 12

4. Coleochaete scutata Brébisson, [L.] A. de .1844.

Thallus multicellular, single layered, slightly irregular; cells radiate from center, cells towards centre quadrate to polygonal, outer oblong, elongate, setae long.

Place of collection: Nandyal tank, on Nymphaea petiole, Date of collection:12.11.19

Collection number: 16

\section{Cosmarium auriculatum Reinsch 1875.}

Cells circular in outline, $47 \mu$ long, $45 \mu$ wide, isthmus $25 \mu$ wide; sinus open, $v$ shaped; semi cell sub circular, basal margin straight, lateral margin truncate with 3-4 medium sized acute granules, upper lateral margin converge to join round to convex apex; wall punctuate; chloroplast axile with two pyrenoids in each semi cell.

Place of collection: Velugodu tank, Date of collection: 13.11.19, Collection number: 28

\section{Dictyosphaerium pulchellum Wood, H.C. 1873 '1872'.}

Colonies nearly spherical and of 4-64 or more cells, cells spherical to ovoid, with a single parietal cup-shaped, chloroplast having a single pyrenoid, cells $3-10 \mu \mathrm{m}$ in diameter, colonies up to $64 \mu \mathrm{m}$ in diameter.

Place of collection: Nandyal tank, Date of collection:12.11.19,Collection number:18

7. Dolichospermum circinale Wacklin, P., Hoffmann, L. \& Komárek, J. (2009).

Trichome solitary, with wide regular spirals, cells spherical, barrel- shaped 8-14 $\mu \mathrm{m}$ wide with gas vacuoles, heterocyst almost spherical 8-12 $\mu \mathrm{m}$ wide, $8-12 \mu \mathrm{m}$ long.

Place of collection: Kurnool tank, Date of collection: 11.11.19, Collection number:07

\section{Gloeotaenium loitlesbergerianum Hansgirg, A. 1890.}

Colony broadly ellipsoid in front view and oblong in side view, cells spherical to ovoid and completely filling the space inside the mother cell wall, gelatinous bands broad, chloroplast with a distinct pyrenoid, colonies $20-80 \mu \mathrm{m}$ in diameter and cells $12-30 \mu \mathrm{m}$ in diameter.

Place of collection: Velugodu Dam, Date of collection:13.11.19, Collection number:24

\section{Microcystis aeruginosa Kützing, F.T. 1846.}

Thallus colonial, microscopic, mucilaginous, spherical to more elongate, lobete, irregular and net like with closely arranged cells, clathrate, spaces $20-40 \mu \mathrm{m}$ wide; mucilage, diffluent, colourless; cells spherical with many aerotopes, cell division transverse, $5 \mu \mathrm{m}$ wide.

Place of collection: Kurnool tank, Date of collection: 11.11.19, Collection number: 09 
10. Microcystis flosaquae Kirchner, O. 1898.

Colony spherical to elliptic, microscopic, not lobete with compactly arranged cells; mucilage colourless, diffuse, do not exceed colony margin, diffluent; cells spherical with several aerotopes, 4-5 $\mu \mathrm{m}$ wide.

Place of collection: Kurnool tank, Date of collection: 11.11.19. Collection number: 09

11. Oocystis borgei Snow, J.W.1903 '1902'.

Cells broadly ellipsoid with rounded ends poles not thickened, chloroplasts $1-4$, parietal, each with a pyrenoid, cells 9-13 $\mu \mathrm{m}$ broad, 9-17 $\mu \mathrm{m}$ long 2-8 celled colonies, enclosing envelope.

Place of collection: Nandyal tank, Date of collection: 12.11.19, Collection number:17

12. Pseudopediastrum boryanum (Turpin) E.Hegewald in Buchheim \& al. 2005.

Colonies circular, compact, cells 8 to 32, without intercellular spaces. Marginal cells incised to form two short spines, inner cells polygonal.

Place of collection: Velugodu Dam, Date of collection: 13.11.19, Collection number: 24

\section{Pseudopediastrum boryanum var. longicorne Tsarenko, P.M. 2011.}

Colony circular, without hole, inner cells wide U shaped, marginal cells deeply U or V shaped, incision reaching below cell outline, lateral margins straight, processes double to one cell length, straight or reflexed; cell wall smooth,

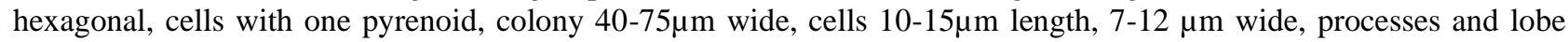
7.5- $10 \mu \mathrm{m}$ length.

Place of collection: Kurnool tank, Date of collection: 11.11.19, Collection number: 05

14. Pseudopediastrum subgranulatum (Raciborski) Lenarczyk in Lenarczyk \& al. 2020:

Colony circular, marginal cells distinctly ; cell wall slightly net like and densely granulate, scabrom, colony 75-110 $\mu \mathrm{m}$ wide, cells $18-20 \mu \mathrm{m}$ length, $15-17 \mu \mathrm{m}$ wide, processes $3 \mu \mathrm{m}$ length.

Place of collection: Nandyal tank, Date of collection: 12.11.19, Collection number:19

15. Scenedesmus arcuatus Lemmermann, E.1899.

Colonies usually 8 -celled, rarely 4 - or 16 celled, curved and with small intercellular spaces, cells in 8 - celled colonies in two series, oblong-ovoid, sometimes slightly angular at the base due to mutual pressure; cells $3.5-9.5 \mu \mathrm{m}$ broad, 8.5-18 $\mu \mathrm{m}$ long.

Place of collection: Nandyal tank, Date of collection: 12.11.19, Collection number:19

16. Scenedesmus ecornis Chodat, R.1926.

Colony of 4-8 cells, cells arranged in a single series, cells attached to each other along most of their length leaving rounded poles, marginal cells semi lunar, convex on outside slightly concave inside, inner cells oblong to elliptic, straight on both sides, poles rounded neither marginal cells nor inner cells possess spines, walls smooth, cells with a prominent pyrenoid and granules, 4 celled colony up to $32 \mu \mathrm{m}$ long, cells $20 \mu \mathrm{m}$ long, $8 \mu \mathrm{m}$ wide.

Place of collection: Nandyal tank, Date of collection: 12.11.19, Collection number: 19

17. Scenedesmus incrassatulus Bohlin, K.1897.

Single celled or in colonies of 2-4 cells, cells in a linear or sub alternating series, fusiform, curved with the outer side convex and the inner side more or less straight or slightly concave, ends of cells stumpy and with apical nodules; cells 5-10 $\mu \mathrm{m}$ broad, 12-28 $\mu \mathrm{m}$ long.

Place of collection: Velugodu Dam Date of collection: 13.11.19, Collection number: 26

18. Scenedesmus bijugatus var. alternans (Reinsch) Hansgirg. 1906.

Colony flat, 8 celled, cells arranged in alternate series, adjacent cells slightly attached, cells ovate-ellipsoid, poles round, $14 \mu \mathrm{m}$ long.

Place of collection: Velugodu Dam, Date of collection: 13.11.19. Collection number: 24

\section{Scenedesmus platydiscus Chodat, R.1926.}

Colonies flat, 8-celled, with oblong, elliptic cells arranged in a double series interstices between cells minute or absent altogether, cells $4.5-7.5 \mu \mathrm{m}$ broad, $8-17 \mu \mathrm{m}$ long.

Place of collection: Nandyal tank, Date of collection: 12.11.19, Collection number: 18 


\section{DOI: 10.17148/IARJSET.2021.81205}

20. Scenedesmus quadricauda Brébisson, L.A. de \& Godey, L.L.1835 '1836'.

Colony of 2-4-8 cells arranged in a linear series, contacted with each other along the whole length, cells linear oblong to linear elliptic, with round poles, marginal cells convex on outer side, bear strong spines one at each pole, inner cells usually do not possess, spines are rarely possess a single spine; cells up to $20 \mu \mathrm{m}$ long, $5 \mu \mathrm{m}$ wide walls smooth.

Place of collection: Kurnool tank, Date of collection: 11.11.19, Collection number: 03

\section{Uronema africanum Borge, 0.1928 .}

Filaments unbranched; basal cell elongate, tapering towards base, 9-10 $\mu \mathrm{m}$ long, $2-3 \mu \mathrm{m}$ broad; terminal cell curved with pointed eng; cells cylindrical, uninucleate, $2-3 \mu \mathrm{m}$ long.

Place of collection: Nandyal tank, Date of collection: 12.11.19, Collection number: 18

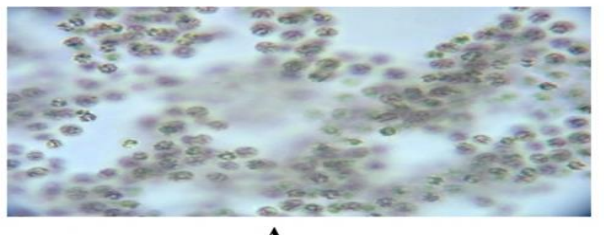

A

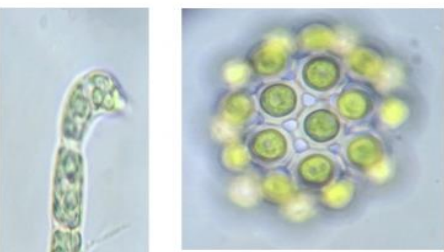

D

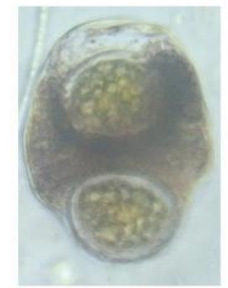

I

$\mathbf{J}$

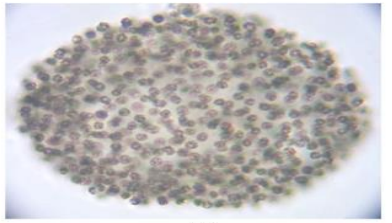

$\mathbf{B}$
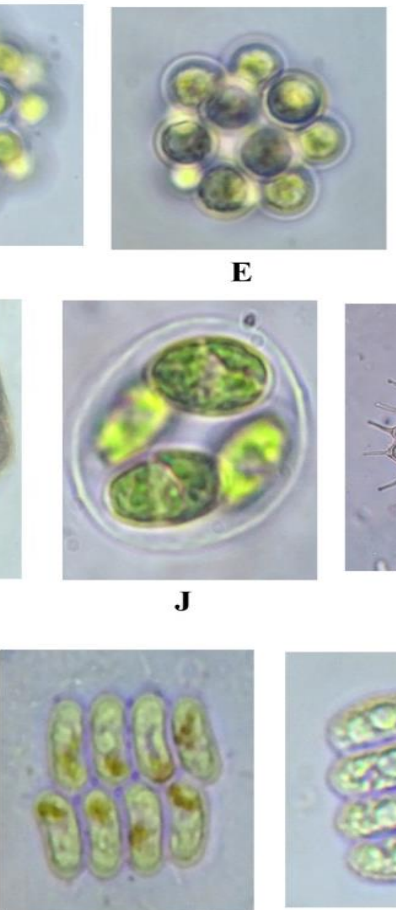

$\mathbf{N}$

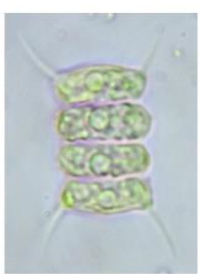

S
E

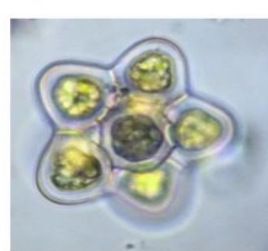

F

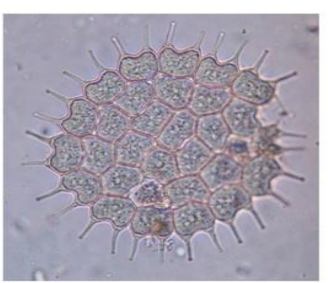

$\mathbf{K}$

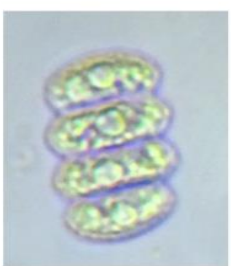

O

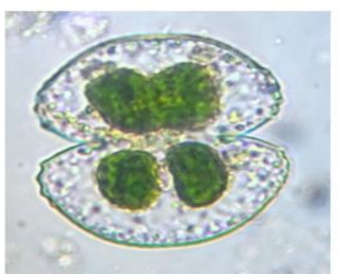

T

P

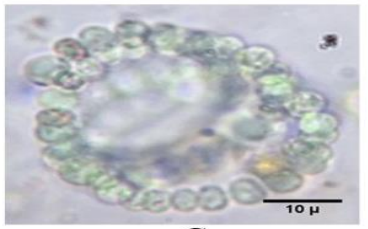

C

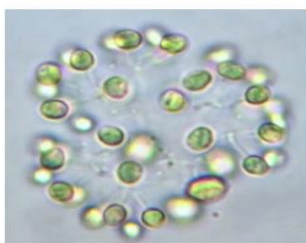

G

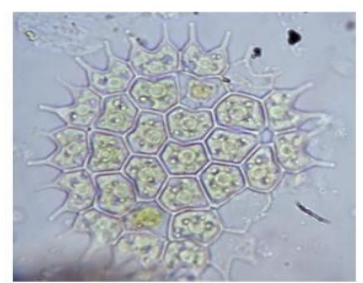

L
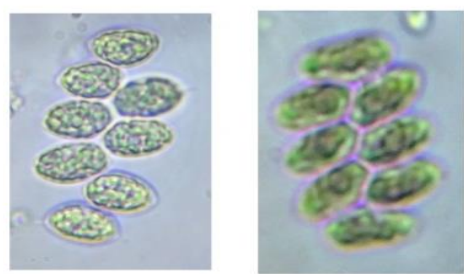

Q

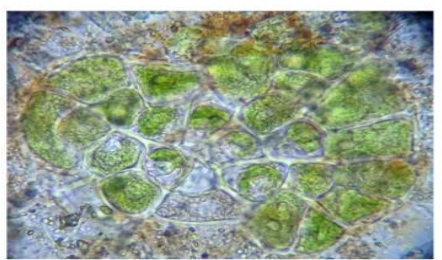

U

Plate: A. Microcystis aeruginosa B. Micro flos-aquae C. Dolichospermum circinale D. Coelastrum cambricum E. C. microporum F. C. proboscideum G. Dictyosphaerium pulchellum H. Uronema africanum

I. Gloeotaenium loitlesbergerianum J. Oocystis borgei K. Pseudopediastrum boryanum var: longicorne L. Pseudopediastrum boryanum M. Pseudopediastrum subgranulatem N. Scenedesmus arcuatus O. S. ecornis P. S. bijugatus var. alternans Q. S. platidiscus R. S. incrassatulus S. S. quadricauda

T. Cosmarium auriculatum U. Coleochaete scutata 


\title{
International Advanced Research Journal in Science, Engineering and Technology
}

\author{
Vol. 8, Issue 12, December 2021
}

DOI: $10.17148 /$ IARJSET.2021.81205

DISCUSSION

The water bodies of Velugodu Dam and Nandyal tank are olegotrophic. Many of chlorococcalean taxa were distributed in these water bodies. Whereas Periphery of water tank at Kurnool is highly polluted and Eutrophic, where Cyanobacteria, Microcystis and Dolichospermum were more prevalent. All the taxa reported are first distributional records to Kurnool District of Andhra Pradesh.

\section{REFERENCES}

$>\quad$ Desikahary TV 1959. Cyanophyta. ICAR. Monograph on Algae, New Delhi. Pp 686.

Gupta, R.K. 2012. Algae of India vol.1. A checklist of Cyanoprokaryota (Cyanophyceae) Botanical Survey of India, Kolkata. pp. 160. $>\quad$ Gupta, R.K. 2012. Algae of India vol.2. A checklist of chlorophyceae, Xanthophyceae, Chlorophyceae and Euglenophyceae. Botanical survey of India, Kolkata. pp. 428.

> Gupta Pratibha 2012a. Algae of India, A checklist of Cyanoprokaryota (Cyanophyceae). Botanical Survey of India, Kolkata Vol. 1: 160

pp.

$>\quad$ Gupta, R.K. 2012b. Algae of India. 2. A checklist of Chlorophyceae, Xanthophyceae, Chrysophyceae and Euglenophyceae. Botanical Survey of India, Ministry of Environment \& Forests. India, Salt Lake \& Kolkata.

$>\quad$ Jyotsna, N., Subba, G.R. and Rao, M.G.N. 2015. A Contribution to the Seasonal Distribution and Biodiversity of Fresh Water Phytoplankton of Karagam Lake, Srikakulam, Andhra Pradesh, India. International Journal of Environment, 4(1): 82-100.

$>\quad$ Kanth S and Gupta p 1998. Algal flora of Ladakh. Scientific publication, Jodhpur, India.pp341.

$>\quad$ Kaparapu, J. and Geddada, M.N.R. 2013. Seasonal Distribution of Phytoplankton in Riwada Reservoir, Visakhapatnam, Andhra Pradesh, India. Notulae Scientia Biologicae, 5(3): 290-295.

Kaparapu, J. and Geddada, M.N.R. 2015. Seasonal dynamics of phytoplankton and its relationship with the environmental factors in Meghadrigedda Reservoir of Visakhapatnam, Andhra Pradesh, India. India. J. Algal Biomass Utln, 6(4): 60-67.

$>\quad$ Madhavarao, D.S. and Rao, G.N. 2016. Seasonal Abundance of Phytoplankton in Relation to Physico-Chemical features of Venkammacheruvu Veeraghattam, Sriakulam (Dist.) AP, India. IOSR J. of Pharmacy and Biological Sci., 11: 91-98.

$>\quad$ Naidu, B.V., Raju, C.P. and Ranganayakulu, G.S. 2018. Taxonomic diversity of Pediastrum simplex in Andhra Pradesh. Bulletin of Pure \& Applied Sciences-Botany, 37(2): 84-88.

$>\quad$ Nandigam, J., Rangaiah, S.G. and Geddada, M.N.R. 2016. A study on seasonal changes of microalgae in relation to the physico-chemical parameters of Satyavaram Pond, Srikakulam Dist, India. Journal of Geo-Marine Sciences (IJMS), 45(12): 1660-1668.

$>\quad$ Philipose MT 1967. Chlorococcales, ICAR. Monographs on Algae, New Delhi.pp 365.

> Prasad BN and Mishra PK 1992. Freshwater algal flora of Andaman and Nicobar Islands. Vol.1. Bishen Singh Mahendrapal singh. Dehradun .pp369.

$>\quad$ Prescot GW 1961. Algae of the Western Great Lakes area. Wm.C.Brown company publishers. Dubuque, Lowa, pp 977.

$>\quad$ Rao, G.M.N. and Pragada, P.M. 2010. Seasonal Abundance of Micro Algae in Pandi Backwaters of Godavari Estuary, Andhra Pradesh, India. Notulae Scientia Biologicae, 2(3): 26-29.

$>\quad$ Rekha, A., Raju, C.P., Chandrasekhar, A. and Sujatha, P. 2016. Studies on Some Chlorococcales from Chittoor District, Andhra Pradesh. India. Intnl. J. of Plant, Animal and Environ. Sci., 6(2): 230-233.

$>\quad$ Randhawa MS 1959.Zygnemaataceae. ICAR. New Delhi pp 474.

$>\quad$ Rekha, A. and Sujathamma, P. 2017. Identification of Scenedesmus species (Meyen) from Tirumala hills, Chittoor district, Andhra Pradesh, India. Intl. J. of Botany Studies., 7: 144-48.

$>\quad$ Rekha, A. and Sujathamma, P. 2018. Micro algae of Vakulamatha Cheruvu in foot of the Tirumala Hills, Chittoor District, Andhra Pradesh. Phykos, 48(1): 18-20.

$>\quad$ Turner WB 1892 The fresh water algae of EastIndia. K. Sv. Vetensk. Akad.Handl 25 1-187.

$>\quad$ Turner, W.B. 1978. The Freshwater Algae (Principally Desmidieae) of East India. Bishen Singh Mahendrapal Singh Publishers, Dehradun, 187 pp., Plates I-XXIII. 